Maciej Maryl*

IBL PAN

\title{
CONVERGENCE AND COMMUNICATION: GENRE ANALYSIS OF THE WEBSITES OF POLISH WRITERS
}

\begin{abstract}
This article categorizes new forms of expressions on writers' websites as means of maintaining communication with readers. The first part is dedicated to inter- and trans-medial analysis of various multimedia materials published on such websites (e.g. biographical notes, photographs, trailers). In the second part the website is analyzed as a hybrid text in which various types of expression are submitted to the main communicative purpose. On both levels of analysis the material is categorized in terms of the communicative function, for, as the author claims, the genre analysis of electronic discourse requires an approach which takes into consideration not only authorial intent and textual features but also the context of online utterance and the role of other partners of communication.
\end{abstract}

Key words: convergence and communication, writers' websites genre analysis, new media, hybrid texts

\footnotetext{
"Beata Pawlikowska: a writer, a traveller, a hunter" (A32) ${ }^{1}$ - a short description posted on this writer's website gives us an idea about the variety of topics we are just about to encounter here. The author presents herself in diverse social roles, as a travel writer, teacher of foreign languages, and a TV and radio personality. On this website one finds a variety of materials: reportages, notes, travel plans, cooking recipes, information about books and TV shows, picture gallery, aphorisms, interviews... More-

* IBL PAN, ul. Nowy Świat 72, 00-330 Warsaw, e-mail: maciej.maryl@ibl.waw.pl

1 The codes referring to individual websites (e.g. A9), and the addresses of quoted subsites (e.g. A9-1) are listed in the bibliography. All quotations from Polish websites were translated by the author.
} 
over, readers can post their own letters, texts or ads ("ISO travel mate"). Those different types of materials (from literature through functional texts to promotional materials and conversations) require a new conceptual framework, capable of accounting for this variety.

The works published in a volume Polska genologia literacka [Polish literary genre theory] (2007) reflect some crucial problems of contemporary genre studies, which struggle to find new categories for texts created in a multimedia culture. Stanisław Balbus writes about the "extinction of genres", understood as a crisis of theory, whose taxonomies and typologies are not sufficient for new kinds of texts (Balbus 2007). Especially problematic are those texts, which draw from different media or semiotic systems. As Seweryna Wysłouch points out, the use of multimedia broke the monopoly of verbal culture and challenged the linguistic definition of a text (Wysłouch 2007: 300). The novelty concerns not only texts but also the entire communication scene, which results in a new array of possible problems and research questions: Edward Balcerzan (2007) investigates a "multimedia genre theory", and Włodzimierz Bolecki proposes a "different genre theory", based on features dismissed by traditional theory, such as media, or communication patterns (Bolecki 2007: 217).

This article does not aim at answering all those questions or proposing a new genre theory. Instead, I am going to discuss a communicational approach towards multimedia writings. I am going to analyze the way in which writers use new, digital media on their websites, along with the change of traditional genres brought about by the Internet. Hence, I will examine those texts not only in the light of literary tradition but also in the context of electronic communication. Although the texts described in this paper are usually considered "functional" or "paraliterary", I leave such classifications aside and concentrate on the forms and functions that those materials bring to a webpage. The main problems with electronic texts are: (1) their double, techno-semiotic nature; (2) the context of utterance which influences the genre status; (3) different levels of analysis.

Firstly, a webpage clearly exposes the double nature of every text, which - according to Stefan Zółkiewski (1980) - should be considered in both semiotic (meaning) and material (technology) aspects. For instance, if we consider a website as a text, we can distinguish between the communicative purpose of the web page (semiotic aspect), and its format (material aspect), which determines the shape of this document. Secondly, one should carefully examine both the communicational status of the utterance and the audience to which it is directed. The very same genre may serve different roles when published online or in print media. Thirdly, if we take 
another look on Beata Pawlikowska's website, we may notice two possible levels of analysis. On the one hand we may investigate various utterances (e.g. reportages, letters, interviews...) as separate texts, on the other we may consider the entire website as a hybrid of texts, which blends the texts from the lower level. We may analyze those materials from two perspectives - either using the tools of intermedial poetics, which deals with various media configurations in singular texts, or apply the transmedial poetics, which focuses on similarities of cultural texts created in different semiotic systems. The former approach highlights the differences between textual types; the latter seems to blur them (cf. Maryl 2009 b).

Those strategies are applied to the materials found on the websites of Polish writers. In the first part of this paper the focus is on the lower level of analysis (i.e. individual types of texts from websites), employing an intermedial perspective. In the second part the higher level (webpages as hybrid texts) is analyzed in the transmedial framework. The analyses were performed on a group of 85 websites of Polish writers. ${ }^{2}$

\section{Texts on writers' websites}

\section{The format, or the material aspect of texts in an intermedial perspective}

It is crucial that a survey of media employed by writers on their websites is defined. I understand 'medium' as a technological means of transmitting semiotic content, agreeing with Grzegorz Godlewski's distinction between 'basic' (word, image, performance) and 'detailed' media (e.g. print, oil painting) (Godlewski 2008: 277-278). The word, for instance, is perceived by Goldewski as a transmitter of the secondary modeling system (semiotic system) of literature (or - in a broader sense - art), whereas its 'detailed media' are "oral utterance, writing, print, electronic audiovisual effects, digital computer and network media" (ibid.: 279). Let us examine, how diverse detailed media serves as carriers of the word on writers' websites.

The electronic word depends on the context of utterance, formed by both the implied role of the reader and the choice of means of communication. Davis and Brewer define electronic discourse as:

2 The bibliography contains only those texts which were explicitly quoted in this article. 
... the two-directional texts in which one person using a keyboard writes language that appears on the sender's monitor and is transmitted to the monitor of a recipient, who responds by keyboard. The recipient may actually be a single individual or a group, large or small, of receivers. (Davis and Brewer 1997: 1).

Electronic discourse differs from "printed" texts (i.e. those which are available either in print, or as digital facsimile, see. Maryl 2009a) insofar that it is deeply rooted in the immediate context and aimed at the reaction of the reader. Let us consider this question on the example of two poems posted by Miłosz Biedrzycki (A4) and Ernest Bryll (A6). On the former's website we find verses bound in collections, just as they appear in print. Thus the reader can navigate the page as if she was walking through a library choosing the collections and individual poems they contain. Bryll, on the contrary, publishes (or "reprints") his poetry in blog posts, usually with reference to current events or holidays. In this situation, the poem obtains double contextualization: chronological (e.g. it is posted on Easter) and situational (it appears on writers' blogs as a poem directed to blog readers who may comment on it).

Apart from the 'printed' and electronic word, writers' websites also contain audio and visual materials. Some authors post the excerpts of their works as audiobooks or, rarely, short movie clips. Usually there are not original productions, but rather adaptations of previous works, such as in the case of Antoni Hukałowicz's poem "Choroszczańskie błonia I" ['Choroszcza common I']. Students from his hometown shot a movie clip which shows the places described in the poem, read by a slightly affected young man (A6-2). Thus, the basic medium of the word is supplemented by the audiovisual sphere.

Literary trailers, short promotional movies, have somewhat different status. It is a fairly new phenomenon, which appeared on the Polish Internet in the middle of the previous decade (see Niemczyńska 2008). The adjective 'literary' is not a genre indication but rather a description of the field of its reference - a literary trailer, like a movie trailer, is an advertisement of a book.

Literary trailers draw from movie aesthetics. Jarosław Klejnocki's crime novel Potudnik 21 [Longitude 21] is promoted by a short clip, which could be mistaken for a cinema-noir movie trailer: black and white pictures, a corpse in the woods, the writer interrogated in a prison cell. ${ }^{3}$ Literary trailers of Wroniec by Jacek Dukaj employ the style of cartoons

\footnotetext{
3 Literary trailers are listed in the bibliography.
} 
(Wroniec 1) and documentaries (Wronice 2). Other stylistic references include experimental cinema (Robert Król), thrillers (Żulczyk, Orbitowski), music clips (Michalak), or amateur videos (Witkowski).

In one of the first conceptualizations of literary trailers phenomenon, Urszula Pawlicka describes multimedia features of this genre: word (subtitles, voice of the narrator, author or an actor), image (pictures, moving pictures), and music (Pawlicka 2008). Although Pawlicka points out to potential threats such trailers may pose to literary works as they - in her opinion - trivialize the books content, one should probably consider this form as simply an audiovisual version of such traditional genres as a note about a book, an excerpt, an interview, a blurb or a cover. A literary trailer comprises of word (information about the work) and image, which transmits a certain message in the same way as a bookcover does: trailers give a visual impression about the genre and the mood of a book. For instance, trailers of thrillers (Żulczyk, Orbitowski) are dark and full of tension highlighted by the music, whereas in presentations of women fiction (Fox, Michalak) the colors are warm and the music is peaceful.

Other visual materials, like writers' pictures, serve similar functions on the one hand they seem to make the person more 'realistic' (one can see what the author looks like), but on the other they could be compared to short biographical notes. There are close links between the aesthetics of an author's picture and the genre of her or his output. This similarity is especially visible amongst the authors writing crime fiction, thrillers and women's fiction. For instance, the homepage of Krzysztof Kotowski (A19), crime and action stories writer, is entirely black and in its center we see the writer with a burning book in his hand. His name is surrounded by a frame covered in blood...Authors' portraits are usually less obvious, and mostly seem to imitate certain visual stylistics (e.g. Klejnocki's A18 and Krajewski's A21 black \& white pictures) or employ clearly symbolic props like a raincoat (Krajewski A22), black glasses (Niemirski), burning candles (Darda A9), leather jacket and a hoodie (Orbitowski A31). Children fiction writers present themselves in warm colors: Paweł Beręsewicz is pictured on a bike, holding a book (A2), and Michał Daniel Mordarski smiles to us from behind a pile of books (A29). Smiles and pastel colors are also to be found in the pictures of female fiction writers - Marlena de Blasi (A10) and Katarzyna Michalak (A28). Other visual materials on authors' websites serve similar functions: background colors, pictures, and book covers... They all convey certain information about the authors, their writings or biographies.

Writers' websites should be then understood as new, multimedia utterances in which medium-specific genres (e.g. crime movies) are freely 
mingled into a multimedia text, subdue to a certain communication function. The information about writers is then conveyed through written, visual (bookcovers, pictures) and audiovisual (trailers) materials, which should be considered as one larger utterance, expressed through diverse media systems.

Henry Jenkins uses the term 'convergence' to describe the content flow between various media platforms (cf. Jenkins 2006). Convergence is a really broad term, which mostly refers to the media industry and the ability to transfer media content from one device to another. In this case I use this term to describe the utterances, whose elements, expressed through different media) complement each other. The best example of convergence on the Polish literary scene would be Jacek Dukaj's Wroniec with its promotional materials: trailers, pictures, wallpapers, animations, book excerpts read by Jan Peszek, songs performed by Kazik and an educational game. Supplementary materials are adapted to the new media reality - users may now choose among different forms of the story, or rather: different gates to the textual world. Quite similarly we may treat links to multimedia materials in electronic discourse, such as posting YouTube or Vimeo videos in blog posts. For instance, a poet Grzegorz Kwiatkowski recommended in his blog a song by Schubert (by posting a link), in order to convey the mood of his own poems in an extra-linguistic way (A25-1). Audiovisual material was used to complement and develop the verbal text.

In a multimedia culture different forms of expression create together one message, becoming a carrier of an utterance. Although those remarks concern mostly functional genres, it is obvious that such an electronic and multimedia "writing" is a dominant characteristic of the Internet environment and perhaps here - not in the complicated hypertextual constructs - lies the future of literary works.

\section{Genres of webpage texts in a transmedial perspective}

Let us take a look at texts from webpages in a transmedial perspective, i.e. genres are considered independently from the media used to convey them. I have already mentioned that the context of utterance is crucial for electronic discourse. Carolyn N. Miller in her programmatic piece "Genre as Social Action" suggests that in order to understand a genre we should understand it in a functional way. A genre analysis should include situational context and the motivation of social actors. 


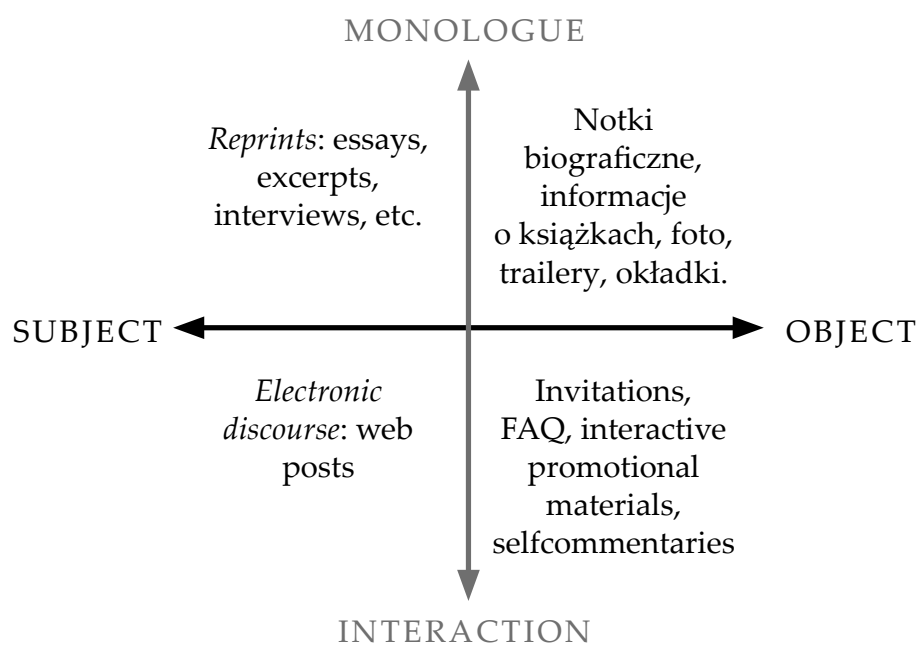

Figure 1. Classification of materials from writers' websites

Approaching those texts from the communicational perspective I am focusing on the form of communication. A similar approach was proposed in Krishnamurthy's study of blogs, which were categorized according to two dimensions: personal vs. topical, and individual vs. community (qtd. in Herrring et al. 2005: 145-146). Since the material analyzed in this paper is different and concentrated on writers, I came out with different dimensions, namely monologue vs. interaction and subject vs. object. Hence, I differentiate the 'monologue' forms (i.e. utterances whose receipent is not clearly defined) from 'dialogic' or 'interactional' utterances (i.e. those targeted at readers). The analysis allows us to distinguish the second level of analysis, which concerns the topic of utterance. Some texts express a writer's social status (the author and his work as the subject), whereas the others concentrate around writer's subjectivity (writer as a speaker) (see. Figure 1). This double dichotomy allows us to understand and classify various texts (expressed through different media) on writers' websites. The very same text can serve different communication functions depending on the context.

\section{Subject/monologue}

The first group of utterances is not immediately connected with the situational context. The main kind of material are reprints, i.e. excerpts from previously published literary works, essays or interviews. Non-literary 
texts are usually of informational matter and they are loosely connected with each other. For instance, on Olga Tokarczuk's website we may find a couple of short stories and a speech the author delivered after being awarded a literary prize. Some writers publish full volumes of poetry (A4, A25), but usually we encounter short excerpts which should encourage readers to buy the entire book.

\section{Subject / interaction}

Far more interestingly, from our perspective are those texts which aim at interaction, i.e. those utterances which were discussed above as electronic discourse. The main textual form in this group could be called a 'web post'. By this I mean all possible texts which employ one or more media and are created in the web environment, being directed to the networked audience. The best example of such an utterance is a blog post, in case of which both forms and the communicational context influence the content and style. A single utterance is usually a part of a series of dated entries, usually commented on by other users (cf. Gumkowska, Maryl i Toczyski 2009, p. 295;. Gumkowska 2009). The category of a 'web post' also consists of other textual forms like comments or welcoming notes on writers' websites. Due to the high subjectivity of the electronic discourse, most of the blog entries are based on traditional, biographical or intimate genres such as a diary, a letter, or autobiography.

\section{Object/ monologue}

This group consists of monological utterances about the writer, i.e. notes about authors and books, pictures, literary trailers, bookcovers. Some writers, e.g. Mariusz Sieniewicz (A34), provide press kits with short notes and high-resolution pictures. The main function of such materials is to promote writers and their output.

\section{Object/ interaction}

The last group consists of the utterances aimed at triggering readers' reaction and cooperation. Writers invite readers to book-readings or events somewhat connected to their writings (e.g. city walks dedicated to the places described in a book). Such utterances serve as an invitation to inter- 
action along with such promotional materials as abovementioned wallpapers or quizzes about the novel (Beręsewicz A2, Mordarski A29).

One also has to distinguish a group of utterances dedicated to writers which mock the interaction like self-presentation in the form of "questions-and-answers". Katarzyna Leżeńska, a female-fiction writer describes herself in a fake interview about the writing process ("Where do you get the ideas? ... How long does it take you to write a book? ... Have you ever worked on two books simultaneously?" A26). Marta Fox describes what she likes and dislikes (A12) and Marek Krajewski interviews himself and answers questions "he had already answered multiple times" (e.g. Why do you write crime fiction? Do you work on a series of short stories? Do you miss the academic career?). A similar strategy is applied by such authors as Jacek Dukaj or Beata Pawlikowska, who publish the answers to frequently asked questions, and therefore avoid direct contact with readers.

\section{Website as text}

At the begining of this article reference was paid to Beata Pawlikowska's website. As we may recall, it contained various multimedia materials created by readers or the author herself, which were later categorized in terms of communication. But what if we want to analyze this website as a whole?

When we adopt the intermedial perspective we pay attention to the characteristics of singular media employed in the utterance. On the other hand, when we choose the transmedial approach, we focus not on the differences between those media but rather on the utterance as a whole. The former approach draws attention to the hybrid nature of electronic utterances, whereas the latter focuses on the message itself. Now, when analyzing websites as texts, I adopt the second approach, treating web pages as hybrid forms.

Concentrating mainly on the communication I will analyze websites in a perspective similar to rhetorical hybrids analysis, as proposed by Kathleen Hall Jamieson i Karlyn Kohrs Campbell (1982). In this perspective genres are understood as "dynamic fusions of substantive, stylistic and situational elements and constellations that are strategic responses to the demands of the situation and the purposes of the rhetor" (ibid.: 146). On the example of eulogies Jamieson and Campbell argue that every genre is "a potential fusion of elements that may be energized or actual- 
ized as a strategic response to a situation" (ibid.). In other words, a eulogy consists of various genres which are subdued to the main communicative intent (i.e. to praise the deceased person).

Although websites as rhetorical structures are less coherent than eulogies one may venture to point out a main communicative intent, which would dominate over various elements of the website. One should also take into consideration the previously mentioned duplicity of electronic texts, which consist of material and semiotic aspects, i.e. communication technologies and the meaning. This problem was elaborated by Askehave and Nielsen in their analysis of "web-mediated genres" (2004). They propose to analyze internet texts in three dimensions: communicative purpose, functional units and rhetorical strategies (ibid. 22-44). Yet, the authors claim, all those dimensions have both reading (semiotic) and navigational (technical) aspects. For instance, the main communicative purpose of a homepage (Askehave and Nielsen's main example) in the reading mode is to introduce "the user to general content of the site" (ibid. 9). However, in the navigation mode, the homepage functions "as the official gateway of the website as it enables the reader to access and navigate the site by providing navigational tools or links that branch off into the website as a whole." (ibid.)

This part of the article analyses the website as a whole in two aspects: its semiotic (or reading) aspect which is considered a genre, whereas its material (or navigational) aspect is understood as a format. A webpage's format is its entire technological side (programming), which shapes the communication and influences a genre by allowing certain forms of publication. A webpage's genre would be understood as its primal communicative purpose, which is visible in the way technological capacities are used. For instance, a blog should be conceived of as a format, i.e. a frequently updated webpage, usually allowing for comments. Yet, this very format can be employed by various genres ranging from travel blogs to simple personal webpages.

\section{The formats of writers' websites}

When assessing a website's format we consider such features as visual aspect (e.g. layout, colors, media) and the content structure (e.g. the list of entries or separate subpages). Among formats used by writers we can distinguish three main types: a simple webpage, blog and vortal. 


\section{Simple webpage}

Although blogs and portals are technically also webpages, we will apply this name to simple websites (e.g. home pages). Such websites are usually quite straightforward, rather static and simple in programming. They usually consist of a homepage and several subpages, which sometimes can serve as categories for content. Dynamic elements, such as a news section or social-network plugins (e.g. Twitter) appear rarely.

A website's structure is usually hierarchical, taking a form of the tree: the homepage ( $1^{\text {st }}$ level $)$ gives users the access to the list of categories $\left(2^{\text {nd }}\right.$ level), which are usually divided into subcategories or indexes ( $3^{\text {rd }}$ level), which in turn direct users to individual pages $\left(4^{\text {th }}\right.$ level). The number of categories and subcategories varies from a couple to a dozen or so. This structure is rooted in the files-and-folders metaphor: all elements of the website are arranged and categorized, so that browsing the webpage is similar to the act of leafing through a book.

\section{Blog}

A blog is a type of a webpage, based on a template, which allows a non-professional user to setup and maintain the service their own. Blogs are usually defined as "frequently modified web pages in which dated entries are listed in reverse chronological sequence" (Herring et al. 2005: 142). The form of a blog resembles a newspaper: entries are usually located in the central part of the website and indexes are located on the edges, along with the author's bio and a blogroll, i.e. list of links to interesting websites or blogging-friends. This format's dynamics is further highlighted by chronological indexes, and dates of entries or comments. A blogger may allow users to post comments under the entries.

\section{Vortal}

The last format type is vortal, i.e. vertical portal. Portals usually contain a large amount of diverse materials, and types of writing, and they usually focus on news (e.g. yahoo.com). Vortals, on the other hand, are less general and more topical. Users may not only comment on posted entries but they can also interact with each other and usually post their own content online. Hence, such websites allow not only for communication 
between writers and reader but they also create a platform for interaction between readers themselves (e.g. such is the case on Beata Pawlikowska's website (A32).

\section{The genres of writers' websites}

Let us now consider writers' websites as genres which are distinguished through the analysis of the content and communicative purpose (i.e. declared and visible goal for running a website). The genres which are distunguished (shopping window, bulletin, filter, blog) could be placed on a spectrum from static, print-like forms serving rather informative functions, which allow a limited feedback from the users, to dynamic, interactive forms, rooted in the electronic discourse. One should also point out that those genres are ideal types and may coexist on individual websites.

\section{Shopping window}

This genre is an occasionally updated, static webpage which main purpose is to provide information about the writer and her or his output. The term was coined by a poet, Miłosz Biedrzycki, who calls his website 'wystawka' ('a small shopping window'). This name depicts well both the shape and goals of such webpages, as well as the static way of presenting the content. Most of the shopping windows are based on a simple webpage format, however some writers, like Antoni Hukałowicz (A17), employ a blog format too.

A shopping window is deeply rooted in print culture - the homepage is an index of content and all categories are organized in a hierarchal way. For instance, on Olga Tokarczuk's website the category "Texts" leads us to an index of articles (A38). Shopping windows are rarely updated, mostly only when an author's new book comes out. They do not serve to function as a news medium, but rather provide basic information about the writer. The communication channels are limited - usually we find the writer's e-mail address or a contact form.

Analyzed websites representing this genre do not contain much current news about the author or upcoming events. The material posted on the shopping window, such as a bio note, book synopsis, photos or excerpts are 'timeless', i.e. they do not require frequent updates. Let us consider Olga Tokarczuk's website (A38): the cover of the newest book visu- 
ally dominates the website. On the top we find the list of categories (bio, books, texts, reviews, various, audio, gallery, contact). Once we compare this website with other shopping windows prepared by the same publisher, Wydawnictwo Literackie (e.g. Ewa Lipska A27, Katarzyna Grochola A13), we see that they are virtually identical. Communication with readers is far less important than providing the information. Although some authors copy the communication patterns of the print culture and publish short 'forewords' (e.g. Rylski A33, Kotowski A19, Wrocławski A40), we may consider such notes as purely expressive, since they do not count on the readers reaction at any rate. Users are usually unable to post comments on shopping windows.

In certain cases the communication with readers is conducted through dedicated subparts of a website, such as visitor log or a discussion board. The former type usually functions as a 'letter to the writer', in which readers frequently express their gratitude and describe their amazing reading experiences. A discussion board, on the other hand, is a platform almost entirely dedicated to readers. Yet, this form of communication is quite scarce among writers' websites and does not attract many readers. For instance, Grażyna Bąkiewicz's forum had only 12 posts in 2 years (A1).

\section{Bulletin}

Krzysztof Beśka's homepage (A3) has a lot in common with a shopping window - the author is the main subject of the site, and the homepage contains basic biographical information and bookcovers. We do not find any direct references to readers, who cannot comment on posts. The main difference lies in the dynamics - the webpage is built on the blog format, so consecutive posts are displayed on the homepage. In other words, static and dynamic elements coexist within one website.

Posts' subjects vary, however it is usually concentrated around the writer and his output. Consecutive information give readers a chance to follow the creative process, learn about writer's inspirations, read the latest reviews of his books and obtain information about upcoming events. Yet, besides these dynamics and the blog form itself, Beśka's website (and many others) is closer to print culture than to electronic discourse. The website functions as a peculiar 'Writer's newspaper', or a bulletin published for unspecified readers. Bulletins provide information about inspirations, reviews and current events, such as author's meetings, media appearances or a book launch (c.f. websites of Julia Hartwig A16 and Błażej 
Dzikowski A11). Hence, this genre is specifically tied to a writer's professional life - if there's no new book, no event or a prize coming, the bulletin goes on standby.

The bulletin usually consists of news, biographical notes and picture galleries. Their main function is to provide the latest news, so there is rarely any community-making involved and commenting is usually disabled (readers can write e-mails instead). Authors interested in interaction with their readers setup a different channel of communication: Marcin Wroński runs both an official bulletin (A41) and a less formal blog (A42) aimed at discussions with readers.

\section{Filter}

Max Cegielski's Blog (A7) is dedicated to a wide range of topics, reflecting the writer's interests: culture of the Far- and Middle-East (reporter), Indian music (musician), and contemporary Polish culture (journalist). Unlike in two previously discussed cases, Cegielski's website is not entirely dedicated to his self-presentation as a writer but rather to external topics. In this sense it serves as an appendix to Cegielski's writings, reflecting the themes his readers are interested in.

The term filter is used in weblogs classification, and describes those websites, which primarily contain "observations and evaluations of external, typically public events" (Herring et al. 2005: 147). In other words, they are topical websites dedicated to certain, quite well defined subjects (e.g. new technologies, crime fiction, home affairs). They play the role of 'live' RSS channels, i.e. they transmit certain news which is relevant from the writer's viewpoint. In a way, filters work like Twitter, a microblogging platform dedicated to "following" short messages sent by authors one wants to follow. The choice of the followed person entails the range of topics one wants to have the access to. Readers interested in certain topics find relevant information on such blogs. Hence, filters consist largely of links to external materials, which are commented on by the author.

The community created around such a website is a topical group they are not so much interested in a writer than in the topics s/he writes about (or in the way s/he describes them). So, on Piotr Kowalczyk's filter (A20) dedicated to electronic literature, topical news is more important than his own writings. Beata Pawlikowska (A32) creates a vortal about travelling, Mariusz Szczygieł (A36) predominantly writes about Czech culture and society and Sylwia Chutnik discusses social issues (A8). This 
'filtering' can be also understood more subjectively - as an emanation of writer's subjectivity. In a way every website is a filter of everyday life, containing material which the author finds relevant, which brings us to blogs.

\section{Blog}

The blog format is not a genre, since technological capacities may be applied in various ways. When we talk about the blog genre we have in mind a rhetorical hybrid, a platform for other genres subdued to the main communicative intent. Blogs are usually defined in communication categories. Herring et al. considers blogs as a "bridging genre", "intermediate between standard web pages and asynchronous CMC" (2005: 161). It should be noted that this statement does not refer to any stylistic features, but rather to the way the communication on the website is organized.

Jakub Żulczyk's blog (A43) is a good example of this genre. The author appears in diverse roles: as a writer, critic, or a private person. A blogger's subjectivity influences the way of writing - the author often makes strong statements and enters into arguments with readers. Apart from criticism and discussions we find here autobiographical narratives, announcements, invitations, or cultural news. The layout and structure are typical for a blog format, strongly underlining the "here-and-now" of communication (newest posts are displayed on the homepage). Moreover, there are no tags, no categories or links to older posts: chronology is the only ordering principle. This "here-and-now" aspect is also visible in the comments, since they mostly refer to actual entries rather than to other sources or the writers' output.

Although blog as a genre is closely linked to a filter (especially in the context of 'filtering' the external world through writer's subjectivity), it is also a very subjective, multifaced genre whichfocuses on a writers' personality. Blog's dynamics make it similar to a bulletin (as described earlier in this paper), however it is not concerned predominantly with a writers social role and self-promotion. The attitude towards readers is also different: Żulczuk often debates with other users, creating conditions for symmetrical communication. This symmetry of communication with readers, together with subjectivity makes up crucial characteristics of this genre.

Maria Cywińska-Milonas (2002) proposes a categorization of blogs according to their communicative characteristics. She distinguishes three kinds: monologic, dialogic and blog-community ("blogowspólnota"). 
Monologic blogs are those where comments are disabled (e.g. Remigiusz Grzela A14). The dialogic type is characterized by limited activity of the readers: comments are rare and mostly directed towards the author (e.g. Jakub Żulczyk A43, Łukasz Orbitowski A31). A blog-community, according to Cywińska-Milonas, is constituted through interactions between the readers. Yet, it must be noted that there are different kinds of such communities. For instance, blogs by Sylwia Chutnik (A8) or Maria Kryńska Szostak (A24) are created within blog-publishing services (iwoman and blogspot), whic encourage other bloggers to contribute and to hold discussions with each other. Somewhat different communities are constituted on individual websites, in the case of which the writer (or publisher) is solely responsible for the interaction (e.g. Jarosław Klejnocki A18, Jerzy Sosnowski A35). Those communities resemble literary salons, where frequent readers discuss various topics dedicated to culture, literature or society.

To conclude, if we consider the entire communicative spectrum of blogs we may distinguish the following instances: monologue, potential dialogue (no comments, although enabled), dialogue, salon, blog-community. Each of these forms is an outcome of both writer's intentions and the actual communication on the website, which largely depends on the readers' interest. Blog as a hybridic genre is predominantly aimed at communication with readers, which makes it a model example of electronic discourse.

\section{Conclusion}

This article aimed at describing diverse texts from writers' websites in a communicational perspective. New electronic means of communication reshape traditional forms of contact between writers and readers and this change leads to three conclusions.

Firstly, the transfer of literary life into the internet environment changes the way in which literary communication functions. Writers are more responsible for connecting with the audience and providing various non-literary materials.

Secondly, the internet context makes communicational approaches towards new genres more important. Taking into consideration both the communicational and communal character of texts from webpages allow us to understand better the functions of such materials and websites as wholes (treated as texts). 
Thirdly, the electronic medium allows us to incorporate into one utterance materials from different media systems. However, we ought to analyze those texts in the context of other genres available on the website.

This is just a snapshot of a fairly dynamic situation. On the one hand, we may observe how one writer after another sets up a webpage and how the online self-presentation strategies are being established. On the other hand, the evolution of electronic communication shows clearly that fairly new forms (e.g. static websites) slowly become obsolete and the writers are going to look for new communication solutions in the nearest future. The internet is now an indispensable part of literary life, which is not limited to self-presentation and commercial moves. The web allows readers to reestablish a symmetric communication with readers.

\section{Bibliography}

Askehave Inger Anne, Ellerup Nielsen 2004, Web-Mediated Genres - A Challenge to Traditional Genre Theory, [in:] Working paper 6, Aarhus: Center for Virksomhedkommunikation.

Balbus Stanisław 2007, Zagłada gatunków, [in:] Polska genologia literacka, eds. D. Ostaszewska i R. Cudak, Warsaw: PWN.

Balcerzan Edward 2007, Nowe formy w pisarstwie i wynikajace stad porozumienia, [in:] Polska genologia literacka, eds. D. Ostaszewska i R. Cudak, Warsaw: PWN.

Bolecki Włodzimierz 2007, O gatunkach to i owo, [in:] Polska genologia literacka, eds. D. Ostaszewska i R. Cudak, Warsaw: PWN.

Cywińska-Milonas Maria 2002, Blogi (ujęcie psychologiczne), [in:] Liternet. Literatura i internet, ed. Piotr Marecki, Cracow: Wydawnictwo RABID.

Davis Boyd H., Jeutonne P. Brewer 1997, Electronic Discourse: Linguistic Individuals in Virtual Space, Albany: State University of New York Press.

Godlewski Grzegorz 2008, Słowo - pismo - sztuka słowa. Perspektywy antropologiczne, Warsaw: Wydawnictwa Uniwersytetu Warszawskiego.

Gumkowska Anna, Maciej Maryl i Piotr Toczyski 2009, Blog to...blog. Blogi oczyma blogerów. Raport z badania jakościowego zrealizowanego przez Instytut Badań Literackich PAN $i$ Gazeta.pl, [in:] Tekst (w) sieci, t. 2. Literatura. Społeczeństwo. Komunikacja, ed. A. Gumkowska, Warsaw: Wydawnictwa Akademickie i Profesjonalne.

Gumkowska Anna 2009, Blogi wobec tradycji diarystycznej. Nowe gatunki w nowych mediach, [in:] Tekst (w) sieci, t. 1 Tekst, jezyk, gatunki, ed. D. Ulicka, Warsaw: Wydawnictwa Akademickie i Profesjonalne.

Herring Susan, Lois Ann Shedit, Elijah Writh i Sabrina Bonus 2005, “Weblogs as a Bridging Genre", Information, Technology \& People, No. 18.

Jamieson Kathleen Hall, Karlyn Kohrs Campbell 1982, "Rhetorical Hybrids: Fusions of Generic Elements", Quarterly Journal of Speech, No. 69. 
Jenkins Henry 2006, Convergence Culture: Where Old and New Media Collide. New York: New York University Press.

Maryl Maciej 2009a, Reprint i hipermedialność - dwa kierunki rozwoju literatury ucyfrowionej, [in:] Tekst (w) sieci, t. 2. Literatura. Społeczeństwo. Komunikacja, ed. A. Gumkowska, Warsaw: Wydawnictwa Akademickie i Profesjonalne.

Maryl Maciej 2009b, „Poetyka tekstu kultury - niedokończony projekt”, Teksty Drugie, No 6.

Miller Carolyn R. 1994, Genre as Social Action, [in:] Genre and the New Rhetoric, ed. A. Freedman, P. Medway, London: Taylor \& Francis.

Niemczyńska Małgorzata I. 2008, Ksiązkowe teledyski w internecie, [in:] Gazeta Wyborcza, No. 59, 10 III.

Pawlicka Urszula 2010, „Trailery literackie - o reklamie literatury pisanej «żywą kamerą»" Niedoczytania, 6 IV, http://niedoczytania.pl/trailery-literackie-o-reklamie-literatury-pisanej-zywa-kamera [10 V 2011].

Wysłouch Seweryna 2007 Nowa genologia - rewizje i interpretacje, [in:] Polska genologia literac$k a$, eds. D. Ostaszewska i R. Cudak, Warsaw: PWN.

\section{Literary trailers}

Dukaj Jacek, Wroniec (1), http://www.youtube.com/watch?v=b-1PVW3po1k (11 V 2011).

Dukaj Jacek, Wroniec (2), http://www.youtube.com/watch?v=S7eTCfrcOws (11 V 2011).

Fox Marta, Kobieta zaklęta w kamień czyli Marta Fox dla dorostych, http://www.youtube.com/ profile?user=WLchannel\#p/u/4/46j61P-hqFU (11 V 2010).

Klejnocki Jarosław, Południk 21, http://klejnocki.wydawnictwoliterackie.pl/strona/14/ (11 V 2011). Król Robert, Pamięć podręczna, http://www.youtube.com/watch?v=ElLZN36z6NE (11 V 2011). Michalak Katarzyna, Poczekajka, http://katarzynamichalak.pl/poczekajka/teledysk (11 V 2011). Orbitowski Łukasz, Nadchodzi, http://www.youtube.com/watch?v=3UJj9g7Ch1k (11 V 2010). Żulczyk Jakub, Instytut (1), http://jakubzulczyk.ownlog.com/2114705,link.html (11 V 2011). Żulczyk Jakub, Instytut (2), http://jakubzulczyk.ownlog.com/2125505,link.html (11 V 2011).

\section{Writers' websites}

A1 - Bąkiewicz Grażyna, http://www.grazynabakiewicz.pl/ (26.01.2011).

A2 - Beręsewicz Paweł, http://www.pawelberesewicz.neostrada.pl/ (12.01.2010).

A3 - Beśka Krzysztof, http://krzysztofbeska.blogspot.com (12.01.2010).

A4 - Biedrzycki Miłosz, http://free.art.pl/mlb/index.html (29.12.2010).

A5 - Bocheński Jacek, http://jacekbochenski.blox.pl (19.01.2011).

A6 - Bryll Ernest, http://www.bryll.pl (19.01.2011).

A7 - Cegielski Max Maksymilian, http://maxmasala.blox.pl (11.01.2011).

A8 - Chutnik Sylwia, http://sylwiachutnik.blog.iwoman.pl/ (14.02.2011).

A9 - Darda Stefan, http://www.stefandarda.pl/ (26.01.2011).

A10 - de Blasi Marlena, http://www.marlenadeblasi.pl/ (26.01.2011).

A11 - Dzikowski Błażej, http://blazejdzikowski.wordpress.com (26.01.2011). 
A12 - Fox Marta, http://martafox.pl/ (20.01.2010).

A13 - Grochola Katarzyna, http://grochola.wydawnictwoliterackie.pl/ (26.11.2011).

A14 - Grzela Remigiusz, http://remigiusz-grzela.bloog.pl/ (26.12.2011).

A15 - Harny Marek, http://www.harny.pl/ (26.01.2011).

A16 - Hartwig Julia, http://juliahartwig.blogspot.com/ (27.01.2011).

A17 - Hukałowicz Antoni, http://www.antonihukalowicz.blogspot.com/ (28.12.2010).

A18 - Klejnocki Jarosław, http://klejnocki.wydawnictwoliterackie.pl/ (29.12.2010).

A19 - Kotowski Krzysztof, http://www.krzysztofkotowski.pl/ (26.01.2011).

A20 - Kowalczyk Piotr, http://www.passwordincorrect.com/ (15.02.2011).

A21 - Krajewski Marek, http://www.marekkrajewski.pl/ (22.12.2010).

A22 - Krajewski Marek, http://www.marek-krajewski.pl/ (26.01.2011).

A23 - Król Robert, http://www.robertkrol.art.pl/ (30.12.2010).

A24 - Kryńska-Szostak Maria, http://studiumczasoprzestrzeni.blogspot.com/ (10.02.2011).

A25 - Kwiatkowski Grzegorz, http://grzegorzkwiatkowski.com/ (12.01.2011).

A26 - Leżeńska Katarzyna, http://www.lezenska.pl/ (27.01.2011).

A27 - Lipska Ewa, http://lipska.wydawnictwoliterackie.pl/ (26.01.2011).

A28 - Michalak Katarzyna, http://katarzynamichalak.pl/ (26.01.2011).

A29 - Mordarski Michał Daniel, http://www.mordarski.pl/ (26.01.2011).

A30 - Niemirski Arkadiusz, http://www.niemirski.com/ (27.01.2011).

A31 - Orbitowski Łukasz, http://orbitowski.pl/ (26.01.2011).

A32 - Pawlikowska Beata, http://www.beatapawlikowska.com/ (9.02.2011).

A33 - Rylski Eustachy, http://www.rylski.pl/ (12.01.2011).

A34 - Sieniewicz Mariusz, http://www.sieniewicz.art.pl/ (12.01.2011).

A35 - Sosnowski Jerzy, http://www.jerzysosnowski.pl/ (11.02.2011).

A36 - Szczygieł Mariusz, http://www.mariuszszczygiel.com.pl/ (27.01.2011).

A37 - Tochman Wojciech, http://www.tochman.eu/ (27.01.2011).

A38 - Tokarczuk Olga, http://tokarczuk.wydawnictwoliterackie.pl/ (29.12.2010).

A39 - Wencel Wojciech, http://wojciechwencel.blogspot.com/ (28.12.2010).

A40 - Wrocławski Bohdan, http://www.pisarz.eu/ (10.02.2011).

A41 - Wroński Marcin, http://marcinwronski.art.pl/ (30.12.2009).

A42 - Wroński Marcin, http://wronski.wordpress.com/ (30.12.2010).

A43 - Żulczyk Jakub, http://jakubzulczyk.ownlog.com/ (01.10.2011).

\section{Quotations from writers' websites}

A25-1 - “Eine Kleine Todesmusik, czyli pośmiertne przyjemności”, http://grzegorzkwiatkowski.com/?p=254 (12.1.2011).

A6-2 - “Film „Choroszczańskie błonia”, http://antonihukalowicz.blogspot.com/2009/03/ film-choroszczanskie-bonia.html (5.1.2011). 